\title{
The Adolescent Self-Regulatory Inventory (ASRI) Adaptation to Portuguese Context ${ }^{1}$
}

\author{
Paulo César Dias ${ }^{2}$ \\ Universidade Católica Portuguesa, \\ Braga, Portugal
}

\author{
José António Garcia del Castillo \\ Universidad Miguel Hernández, \\ Alicante, Spain
}

\author{
Kristin L. Moilanen \\ West Virginia University, Morgantown- \\ WV, United States of America
}

\begin{abstract}
In this study we present the results of the adaptation of the Adolescent Self-Regulatory Inventory (ASRI) to Portugal. The measure was used with two samples of high school students to which ASRI was administered with Self-Regulation Scale as control measure. In the first study the measures were administered to 823 adolescents and the construct validity analysis was assessed with exploratory factor analysis. The results allow us to find an adequate structure with proper psychometric properties, in their construct and content validity, and reliability. A second study involved 435 adolescents, being tested three models using confirmatory factor analyses. The final version of the ASRI-2 presents an acceptable fit of the data in construct and concurrent validity, given its moderate or high correlation with academic success and substance use. The implications of this new approach to the self-regulation study are discussed and directions to further studies are suggested.
\end{abstract}

Keywords: self-regulation, adolescence, adjustment, psychometrics

\section{Adaptação do Inventário de Autorregulação na Adolescência Para o Contexto Português}

Resumo: O objetivo deste estudo foi apresentar os resultados da adaptação do Inventário de Autorregulação na Adolescência (IARA) para Portugal. O instrumento foi testado com duas amostras de estudantes do ensino secundário com a Escala de Autorregulação como medida de controle. No primeiro estudo, os instrumentos foram testados junto de 823 adolescentes e a análise de validade de construto foi feita com recurso à análise factorial exploratória. Os resultados indicaram uma estrutura apropriada com propriedades psicométricas adequadas referentes à validade de conteúdo e construto, e fidelidade. Um segundo estudo envolveu 435 adolescentes, sendo testados três modelos com análise factorial confirmatória. A versão final do IARA-2 apresenta valores de ajustamento aceitáveis em termos de validade de contruto e concorrente, dadas as correlações moderadas a elevadas com o sucesso acadêmico e uso de substâncias. As implicações desta nova abordagem ao estudo da autorregulação são discutidas e direções para próximos estudos são sugeridas.

Palavras-chave: autorregulação, adolescência, ajustamento, psicometria

\section{Adaptación del Inventario de Autorregulación en la Adolescencia Para el Contexto Portugués}

\begin{abstract}
Resumen: En este estudio se presentan los resultados de la adaptación del Inventario de Autorregulación en la Adolescencia (IARA) para Portugal. El instrumento fue administrado con dos muestras de estudiantes de secundarias públicas con la Escala de Autorregulación como medida de control. En el primer estudio, los instrumentos fueron testados con 823 adolescentes y la validez de constructo se evaluó con análisis factorial exploratorio. Los resultados indicaron una estructura apropiada con propiedades psicométricas adecuadas respecto a su validez de contenido y constructo y fidelidad. Un segundo estudio involucró 435 adolescentes, testando tres modelos con análisis factorial confirmatoria. La versión final del IARA-2 muestra valores de ajuste satisfactorios en términos de validez concurrente y de constructo, ante las correlaciones moderadas a altas con el éxito académico y uso de sustancias. Las implicaciones de este nuevo enfoque para el estudio de la autorregulación son discutidas y direcciones para futuros estudios son sugeridas.
\end{abstract}

Palabras clave: autorregulación, adolescencia, ajuste, psicometría

Adolescence is characterized by the reconfiguration of relationships with peers and family, increased academic stresses, pressures to choose career paths, among other

\footnotetext{
1 Paper derived from doctoral dissertation of the first author under the advisory of the second author in the Graduate Program of Health Psychology at the Universidad Miguel Hernández, Spain.

Support: Strategic Program of the Centre for Philosophical and Humanistic Studies, funded by Foundation for Science and Technology (PEst-OE/FIL/UI0683/2014)

2 Correspondence address:

Paulo César Dias. Faculdade de Filosofia, Praça da Faculdade, 1, 4710-297. Braga, Portugal. E-mail: pcdias@braga.ucp.pt
}

individual challenges (Zimmer-Gembeck \& Skinner, 2008). Thus, successful adaptation appears to depend upon the ways in which individuals manage their emotions, think constructively, regulate and direct their behaviours, and modify their contexts to change or diminish sources of stress (Zimmer-Gembeck \& Skinner, 2011). In other words, adolescents' self-regulatory abilities can play a central role in this phase, in human functioning, resilience, and overall well-being (Elliot, Thrash, \& Murayama, 2011; Garcia del Castillo \& Dias, 2009; Gardner, Dishion, \& Connell, 2008; Hofer, Busch, \& Kärtner, 2011). Several studies underline 
the role of this process in the explanation of learning, motivation, and academic success (McClelland \& Cameron, 2011; Zimmerman, 2008) but also in physical exercise practice (Annesi \& Gorjala, 2010; Hagger, Wood, Stiff, \& Chatzisarantis, 2010; MacDonald \& Palfai, 2008), substance use prevention (Garcia del Castillo, Dias, \& Castelar-Perim, 2012; Garcia del Castillo, Dias, Diaz-Pérez, \& CastilloLópez, 2012; Gardner, Dishion, \& Posner, 2006; Wills \& Dishion, 2004), or others.

Despite widespread agreement among researchers and theorists that adolescent self-regulation is an important factor in the overall adjustment in adolescence, there is less agreement among scholars regarding how self-regulation should be conceptualized and measured during this phase. In fact, many of these studies are based on models designed for adults, allowing the emergence of doubts and inconsistencies in their application to the adolescent population (Gibbons, Gerrard, Reimer, \& Pomery, 2006). From a dispositional approach, self-regulation is conceptualized as an individual variable, which includes the knowledge and previous experiences of a person about the necessary actions to achieve a goal or behaviour (Diehl, Semegon, \& Schwarzer, 2006). This approach focuses at the individual, his personal abilities and skills (Gestsdottir, Bowers, von Eye, Napolitano, \& Lerner, 2010; Luszczynska, Diehl, GutiérrezDoña, Kuusinen, \& Schwarzer, 2004). That doesn't necessarily mean that the actions of individuals are unified, but conceptualized as a relatively stable and persistent process (Lerner et al., 2011; Luszczynska et al., 2004). This is also a tendency in the conceptualization of self-regulation, according to developmental theory (Gestsdottir \& Lerner, 2008; Moilanen, 2007), as an ability to activate, monitor, and inhibit behaviour, attention, emotions or cognitive processes in a flexible and adjustable way as a response to internal or external stimuli, for the achievement of desired outcomes (Demetriou, 2000; Moilanen, 2007).

However, several questions have then been raised by theorists closer to the developmental areas. In a conceptual and methodological review of 123 measures of self-regulation from childhood to adulthood, Moilanen, Goodvin, Raffaelli, and Crockett (2009) verified that measures tend to present limited empirical scrutiny and to focus primarily on the regulation objectives at most immediate or short-term, which could be operationalized as the control of impulses, control of attention and emotional control or regulation of the immediate context. However, the time perspective is quite different over the course of life and there is need to distinguish and evaluate essential long-term components of self-regulation (Moilanen, 2007). Long-term self-regulation would involve impulse control or direction of the effort for a period of time, several weeks, months, or years. This is the case, for example, when an adolescent takes a course to achieve career goals, or keeps saving money to buy an expensive object. This crucial aspect of self-regulated behaviours that take place during adolescence has been verified in studies about school performance (Bilde, Vansteenkiste, \& Lens, 2011; Husman \& Lens, 1999; Miller \& Brickman, 2004) or health behaviours (Hall \& Fong, 2007; Zimbardo \& Boyd, 1999), but has not been consistently represented in instruments. Given the developmental challenges that have not been consistently represented in assessment instruments, there is a need to promote research based on sound knowledge of developmental science (Silbereisen \& Lerner, 2007).

Therefore, in this paper we present the results of the Portuguese adaptation of the Adolescent Self-Regulatory Inventory (ASRI), a developmentally appropriate measure to evaluate short and long-term self-regulation (Moilanen, 2007). This measure was originally tested with 169 students from the 6th, 8th and 10th grades of a US school with satisfactory validity and reliability. To this instrumental study, the requirements for the adaptation of psychological measures were followed (Borsa, Damásio, \& Bandeira, 2012; Carretero-Dias \& Pérez, 2007), considering two studies with independent samples to evaluate the factor structure, with exploratory and confirmatory factor analysis (Henson \& Roberts, 2006). Despite both might be used to the validity evaluation, the first one is specially used for theorybuilding, while the second one is used primarily for theorytesting (Henson \& Roberts, 2006; Matsunaga, 2010). That way, we start exploring the latent structure of the measure in Portuguese population to deepen our analysis and confirm the theoretical model in the second study.

\section{Method - Study 1}

The first study aims examine the latent factor from several observed variables (Henson \& Roberts, 2006), and that way explores validity of the ASRI in Portuguese adolescents. Given some limitations of the Exploratory Factor Analysis, we gathered data from a broader sample to which we applied the inventory and Schwarzer (1999) Selfregulation Scale as control measure.

\section{Participants}

The sample of the study was composed by 823 adolescents from public high schools at the north of Portugal, $27.7 \%$ from the 10th grade $(n=228), 38.5 \%$ from the 11th grade $(n=317)$ and $33.8 \%$ from the 12 th grade $(n=278)$. Individual ages varied from 14 to 20 years $(M=16.38, S D=1.09)$, and the majority were of the female gender $(61.2 \%, n=503)$.

\section{Instruments}

Adolescent Self-Regulatory Inventory - ASRI (Moilanen, 2007). This is a 36 item measure that evaluates the degree to which adolescents are able to activate, monitor, maintain, inhibit, and adapt their emotions, thoughts, attention, and behaviour. The Inventory has a dimensional 
structure developed specifically to assess adolescent short and long term self-regulation. Short-term self-regulation dimension relates to impulse, attention and emotional regulation toward immediate objectives. Long-term selfregulation dimension involves the evaluation of adolescent efforts to control impulse, attention and emotional regulation toward objectives that cover a longer period of time (as career goals, saving money, etc.). Respondents rate how true each item is for them in a Likert-type response scale, ranging from 1 (not at all true for me) to 5 (really true for me).

Self-regulation Scale - SRS (Schwarzer, 1999). This is an unidimentional measure with 10 items that evaluates attention control in goal-directed behaviour. Respondents answer using a closed answer response scale ranging from 1 (not all true) to 4 (totally true). This measure was adapted to Portuguese adolescents demonstrating good psychometric properties in validity and reliability (Cronbach's $\alpha=.78$ ) (Dias, Garcia del Castillo, \& Schwarzer, 2008). In the present sample, the Cronbach's $\alpha$ was .67 .

\section{Procedure}

Data collection. With the authorization of the author of the original version of the ASRI, the measure was translated into Portuguese and back translated into English in order to verify its linguistic and cultural adaptation. The measure was then presented to a pilot group and the final version was tested in a non-probabilistic sample of high school students, by geographical proximity of the research center, in their classrooms, during normal class time.

Data analysis. The data was then coded and analysed with SPSS version 17. An Exploratory Factor Analysis (EFA) of Principal Components with varimax rotation was used to evaluate validity and Cronbach's alpha to evaluate reliability. Concurrent validity was assessed correlating the inventory structure factors with the self-regulation scale (Schwarzer, 1999).

\section{Ethical Considerations}

After the school direction and youth's parents' consent to this research, adolescents were informed by a researcher of the voluntary nature of the research, that all their answers were anonymous and confidential. After this explanation, students signed the Terms of Free, Prior and Informed Consent and were presented to the questionnaires. Students who had no parental consent or didn't volunteer to participate in the research were given academic tasks to do during the data gathering.

\section{Results}

\section{Examination of Validity}

With the application of the Bartlett sphericity test and Kaiser-Meyer-Olkin, we observed values of 3727.34 $(p \leq .001)$ and .85 , showing that the data was adequate for factorial analysis. The ASRI was submitted to EFA forcing the extraction of two factors, as suggested in the original study (Moilanen, 2007). The factor 1, with an eigenvalue of 4.87 , explains $16.978 \%$ of the variance and is composed by most of the long-term self-regulation items. The second factor, with an eigenvalue of 2.47 that explains $8.53 \%$ of the variance, is composed by the most of the short-term items.

However, this first analysis suggested some limitations in some item loadings, being deleted all the items that presented loadings below .30, the items that didn't differentiate between short and long-term self-regulation and items who presented high loadings in other than the original factor. The remaining 11 items for the short-term selfregulation and 11 items for the long-term were then studied with respect to their concurrent validity and reliability.

To ensure concurrent validity, was tested the relationship between the ASRI and the SRS. As we can see in Table 1, a moderate correlation was found between the SRS and shortterm $(r=.40, p<.01)$ and higher correlation with long-term self-regulation $(r=.58, p<.01)$, according to Pestana and Gageiro (2005).

Table 1

Correlations Between Adolescent Self-Regulatory Inventory and Control Measure

\begin{tabular}{lccc}
\hline & & 1 & 2 \\
\hline 1 & ASRI - Short-term & - & \\
2 & ASRI - Long-term & $.28^{* *}$ & - \\
3 & SRS & $.40^{* *}$ & $.58^{* *}$ \\
\hline
\end{tabular}

Note. ASRI: Adolescent Self-Regulatory Inventory. SRS: Selfregulation Scale.

$* * p<.01$ (2-tailed)

\section{Reliability}

Cronbach's alpha provided internal consistency values of .72 in long-term self-regulation and .84 in short-term self-regulation.

\section{Differential Studies}

There was no correlation between self-regulation and age, whereas in the long $(p=.926)$ or short-term $(p=.839)$. In what concerns to gender, a significant difference was found only for long-term self-regulation $\left[t_{(531.326)}=2.465, p=.014\right]$ with average higher scores within girls $(M=74.038, S D=9.573$ to $M=72.032, S D=11.110)$.

\section{Method - Study 2}

The second study aimed to contribute to the development of the theoretical model that underlies the ASRI. Given the novelty of this measure, new items were written and discussed with specialists to a better comprehension of self-regulation in this developmental phase. Fourteen items theoretically 
related to short-term self-regulation and 13 to long-term dimension were mixed with the existing items of the ASRI and administered again with the SRS (Schwarzer, 1999) to analyse concurrent validity. Confirmatory Factor Analysis was used to ensure that the psychometric properties of the measure are theoretically and empirically sound (Henson \& Roberts, 2006; Matsunaga, 2010) with a sample between 200 and 500 adolescents, according to literature (Pilati \& Laros, 2007).

\section{Participants}

The sample for this study was composed by 435 Portuguese public high school students, $52.2 \%$ from the 10 th grade $(n=227), 36.8 \%$ from the 11 th $(n=160)$ and $11 \%$ from the 12th $(n=48)$. The participants' ages varied from 14 to 19 years $(M=16.06, S D=1.00)$ being in majority female $(57.5 \%, n=248)$.

\section{Instruments}

Were used the 22 original items from the Adolescent Selfregulatory Inventory that resulted from the previous study, 11 items for the short-term self-regulation and 11 items for the long-term, with the 27 new items. As a control measure the Selfregulation Scale (Schwarzer, 1999) was used. The measures were collected with a brief demographic questionnaire.

\section{Procedure}

Data collection. After analysing the data of the first study, the new items were mixed with the 22 ASRI items that resulted from the previous study. The measures were then tested again with a convenience sample of public high school students, in their classrooms, during the normal class hours.

Data analysis. The data was submitted to a Confirmatory Factor Analyses (CFA) conducted in M-Plus version 4.0 (Muthén \& Muthén, 2004) to evaluate the adequacy of the structure of the ASRI-2. The minimal requirements for good model fit were a non-significant $\chi^{2}$-fit statistic, a $\chi^{2}$-fit $/ d f$ ratio of less than 3, a Comparative Fit Index (CFI) greater than.90, a Root Mean Squared Error of Approximation (RMSEA) ranging from.05 to.10, and a Standardized Root Mean Square Residual (SRMR) close to 0 (Kleine, 2010). Validity was examined using SPSS v. 17.0. The construct validity of the ASRI-2 was evaluated through an examination of the correlations between the latent ASRI-2 scales and the latent comparison measures of self-regulation. Finally the concurrent validity was evaluated through an examination of correlations between the latent ASRI-2 scales and several indices of academic performance and substance use behaviors.

\section{Ethical Considerations}

As in the previous study, school and parents' consent was gathered and adolescents were informed of the volunteer, anonymity and confidentiality of the collected data. After the explanation, the Terms of Free, Prior and Informed Consent was signed and the questionnaires presented to students with parental consent and who volunteered to this research.

\section{Results}

\section{Confirmatory Factor Analyses}

Single factor model. In this initial single-factor model, all items from the long-term and short-term scales were constrained to load on one factor. The single-factor model did not provide an adequate fit to the data, $\chi^{2}$ fit $(860)=2240.57$, $p<.001, \chi^{2}$ fit $/ d f$ ratio $=2.60, \mathrm{CFI}=.61, \mathrm{RMSEA}=.061$ $(90 \%$ confidence interval $=.058-.064), \mathrm{SRMR}=.069$. All indicators except for item 34 loaded on the single factor $(\lambda=.13, p>.05)$, and item 16 loaded rather weakly $(\lambda=.23$, $p<.05)$. Five items' loadings exceeded 1.00, qualifying as Heywood cases (Heywood, 1931).

Two factor model. A two-factor solution in which the long-term and short-term self-regulation factors were allowed to correlate was also evaluated. Like the single factor model, the two-factor model did not provide a fully adequate fit to the data, $\chi^{2}$ fit $(859)=2186.02, p<.001$, $\chi^{2} \mathrm{fit} / d f$ ratio $=2.54, \mathrm{CFI}=.62, \mathrm{RMSEA}=.060(90 \%$ confidence interval $=.057-.053), \mathrm{SRMR}=.070$, but the two-factor model fit the data significantly better than the single-factor model, $\Delta \chi^{2}$ fit $(1)=54.55 p<.001$. The longterm and short-term factors were strongly correlated $(r=.82$, $p<.001)$. All items loaded significantly on their specified factor, although some items' loadings were weaker than conventional standards. No Heywood cases emerged in the two-factor model, and no items loaded on both factors. The model modification indices indicated that the model fit could be improved by allowing several items to correlate.

Revised two-factor model. A final model was fit to the data, corresponding to the two factor model with six correlations between indicator residual variances (Table 2). Specifically, correlations were specified between items 19 and 29, items 15 and 25, items 17 and 29, items 10 and 13, 3 and 46 , and 15 with 22 . These changes collectively improved model fit: $\chi^{2}$ fit $(853)=1949.48, p<.001, \chi^{2}$ fit $/ d f$ ratio $=2.29$, $\mathrm{CFI}=.69$, RMSEA $=.054(90 \%$ C. I. $=.051-.058)$, $\mathrm{SRMR}=.07, \Delta \chi^{2}$ fit $(6)=236.54, p<.001$. The two ASRI-2 factors were positively correlated $(r=.59, p<.001)$.

\section{Examination of Validity}

Construct and concurrent validity. As presented in Table 3, both ASRI-2 factors were positively and strongly correlated with the comparison measure. The correlations were strong with the Schwarzer (1999) scale (short-term and long-term $r_{\mathrm{s}}=.59$ and .56).

Additional correlations were examined in order to confirm that adolescents' responses on the ASRI-2 were statistically associated with constructs theoretically and empirically linked to self-regulation. Both short and longterm self-regulation factors were associated with academic 
Table 2

Confirmatory Factor Loadings of the ASRI-2

\begin{tabular}{|c|c|c|}
\hline \multirow{2}{*}{ Item Text } & \multicolumn{2}{|c|}{ Factor Loadings } \\
\hline & Short-Term & Long-Term \\
\hline I give up when things take longer than I'd planned. & & .51 \\
\hline I lose items if I don't put them away immediately after using them. & .51 & \\
\hline If something isn't going according to my plans, I change my actions to try and reach my goal. & & .44 \\
\hline I give up on my homework if I don’t understand it. & .92 & \\
\hline I can find ways to make myself study even when my friends want to go out. & & .86 \\
\hline I turn in my homework on time. & & .85 \\
\hline When I'm bored I fidget or can't sit still. & .42 & \\
\hline I stop to think about the short-term consequences of my words and actions. & .41 & \\
\hline I procrastinate on small tasks. & .78 & \\
\hline Little problems detract me from my long-term plans. & .58 & \\
\hline I do unexpected things without thinking of the long-term consequences. & 1.00 & \\
\hline I forget about whatever else I need to do when I'm doing something really fun. & .96 & \\
\hline During a dull class, I have trouble forcing myself to start paying attention. & .63 & \\
\hline I find ways to occupy my mind when I'm stuck in line behind slow people. & & .22 \\
\hline If there are other things going on around me, I find it hard to keep my attention focused on whatever I'm doing. & .69 & \\
\hline I never know how much more work I have to do. & .88 & \\
\hline After an interruption, I don't have any problem resuming my concentrated style of working. & .58 & \\
\hline It's hard to start making plans to deal with a big project or problem, especially when I'm feeling stressed. & .62 & \\
\hline I can't get started if I'm not interested. & .67 & \\
\hline I can stay focused on my work even when it's dull. & & .67 \\
\hline I can stop myself from doing things like throwing objects when I'm mad. & & .53 \\
\hline I miss important deadlines because I'm disorganized. & & .99 \\
\hline I work carefully when I know something will be tricky. & & .74 \\
\hline I am usually aware of my feelings before I let them out. & & .55 \\
\hline I am usually aware of my feelings before I let them out. & & .55 \\
\hline I overreact to small problems. & .53 & \\
\hline In class, I can concentrate on my work even if my friends are talking. & & .56 \\
\hline $\begin{array}{l}\text { When I'm excited about reaching a goal (e.g., getting my driver's license, going to college), it's easy to } \\
\text { start working toward it. }\end{array}$ & & .69 \\
\hline I can find a way to stick with my plans and goals, even when it's tough. & & .79 \\
\hline I can slow myself down when I want to. & .41 & \\
\hline When I have a big project, I can keep working on it. & & .81 \\
\hline I get carried away emotionally when I get excited about something. & .21 & \\
\hline I can resist doing something when I know I shouldn't do it. & & .64 \\
\hline I procrastinate when starting big projects. & & .81 \\
\hline I keep track of my homework so I won't forget to do it. & & 1.00 \\
\hline I keep track of my performance in school throughout the semester. & & .83 \\
\hline I don't allow anything to distract me from my daily plan of action. & .37 & \\
\hline I try the same approach over and over even when it does not work (I get stuck). & & .40 \\
\hline I like to act on a whim. & & .61 \\
\hline I obey my parents or teachers when they tell me not to do something. & & .66 \\
\hline I neglect my responsibilities (e.g., homework, chores) when I'm having fun. & & .66 \\
\hline Somebody else has to help me get started on complicated tasks. & & .65 \\
\hline I lose enthusiasm when things get tough. & & .44 \\
\hline I can't think more than one step ahead on any task. & .37 & \\
\hline
\end{tabular}

Note. All loadings are unstandardized. 
Table 3

Correlations Between Scales, Self-Reported Grades, and Self-Reported Behavior

\begin{tabular}{|c|c|c|c|c|c|c|c|c|c|c|c|c|}
\hline & & 1 & 2 & 3 & 4 & 5 & 6 & 7 & 8 & 9 & 10 & 11 \\
\hline 1 & ASRI - Short-term & & & & & & & & & & & \\
\hline 2 & ASRI - Long-term & $.59 * *$ & & & & & & & & & & \\
\hline 3 & SRS & $.59 * *$ & $.56^{* *}$ & & & & & & & & & \\
\hline 4 & Hours of study at home & $.23 * *$ & $.42 * *$ & $.25 * *$ & & & & & & & & \\
\hline 5 & Math grade & $.15^{* *}$ & $.25 * *$ & $.24 * *$ & $.19 * *$ & & & & & & & \\
\hline 6 & Portuguese grade & $.15^{* *}$ & $.36^{* *}$ & $.25 * *$ & $.28 * *$ & $.62 * *$ & & & & & & \\
\hline 7 & Actually do you use any substance? & $.10^{*}$ & $.19^{* *}$ & .04 & .06 & $.12 *$ & $.15^{* *}$ & & & & & \\
\hline 8 & Actually do you drink regularly? & $.12 *$ & $.19^{* *}$ & $.10^{*}$ & .08 & $.17 * *$ & $.18 * *$ & $.51 * *$ & & & & \\
\hline 9 & Actually you smoke regularly? & .05 & $.20 * *$ & .04 & .05 & .08 & $.11 *$ & $.86^{* *}$ & $.33 * *$ & & & \\
\hline 10 & $\begin{array}{l}\text { In the previous month how many } \\
\text { cigarettes you smoke per day? }\end{array}$ & -.10 & $-.24 * *$ & $-.13 * *$ & $-.10 *$ & $-.16^{* *}$ & $-.16^{* *}$ & $-.45 * *$ & $-.68 * *$ & $-.34 * *$ & & \\
\hline 11 & $\begin{array}{l}\text { In the previous month how many } \\
\text { days you drink alcohol? }\end{array}$ & $-.12 *$ & $-.24 * *$ & $-.11 *$ & -.01 & -.07 & -.01 & $-.44 * *$ & $-.24 * *$ & $-.49 * *$ & $.45^{* *}$ & \\
\hline 12 & $\begin{array}{l}\text { How many times you get drunk in } \\
\text { previous month? }\end{array}$ & $-.16^{* *}$ & $-.30 * *$ & $-.18 * *$ & $-.10 *$ & $-.12 *$ & $-.14 * *$ & $-.41 * *$ & $-.30 * *$ & $-.45 * *$ & $.42 * *$ & $.57 * *$ \\
\hline
\end{tabular}

$* p<.05 ; * * p<.01$ (2-tailed).

performance and behavior: high levels of both dimensions of self-regulation were associated with studying a greater number of hours at home and better grades in math and Portuguese. Long-term ASRI-2 scores were more strongly associated with hours of studying at home and Portuguese grades. With two exceptions, both factors were also associated with substance use behavior. High levels of shortand long-term self-regulation were associated with current absence of substance use, such as tobacco use, fewer days of alcohol use, and fewer times they get drunk. Additionally, high levels of long-term self-regulation were associated with absence of alcohol use, and fewer cigarettes smoked.

\section{Differential Studies}

Considering self-regulation according to gender and age variables, we could find no relation with this second variable, whereas in the long $(p=.962)$ or short-term $(p=.570)$. As presented in study 1 , a significant gender difference was found in long-term self-regulation $\left[t_{(361)}=-6.297\right.$, $p<.01]$ with average higher scores within girls $(M=88.721$, $S D=9.490$ to $M=81.806, S D=11.109$ ).

\section{Discussion}

This paper aimed to present the Portuguese version and the improvement of a new measure for the evaluation of selfregulation in adolescence, the Adolescent Self-Regulatory Inventory (Moilanen, 2007). This is a relatively recent instrument, which is in translation and adaptation process to several countries, as a way to overcome limitations arising from the application of adult self-regulation models to adolescence (Gibbons et al., 2006; Moilanen et al., 2009). In theoretical terms, the assumed perspective has been cited in other studies in this field (Gestsdottir et al., 2010; Gestsdottir \& Lerner, 2008; Lerner et al., 2011), which encourage researchers interested in this issue to continue the empirical studies.

Thus, the first study aimed to adapt the existing version of the ASRI to the Portuguese population, exploring the latent structure of the items with Exploratory Factor Analysis. With the elimination of items that could decrease the discriminative power of the instrument, a version with good psychometric properties was reached, either in its validity or fidelity, and with a positive correlation with an existing self-regulation scale adapted to Portuguese population (Dias et al., 2008).

The inclusion of new items, intentionally developed to evaluate short-term and long-term dimensions, increased the collected information about self-regulation and maintained the psychometric properties of the measure. Despite the need to introduce some modification indices on items with a closer meaning, Confirmatory Factor Analysis provided a theoretically and empirically satisfactory solution in line with the original two-factor model that distinguishes short and long-term self-regulation, maintaining the correlation with the control measure and equivalent results at the differential studies. Regarding gender, despite conflicting results in the literature, there is a tendency for girls to present higher self-regulation, what tends to be associated with evolutionary issues or least controlling parenting practices over boys (McCabe \& Brooks-Gunn, 2007; Raffaelli, Crockett, \& Shen, 2005). Also in line with existing research, the results tend to reflect the stability of self-regulation over time (Raffaelli et al., 2005).

The results also highlight the relation between selfregulation and academic and substance use variables, in line with previous research. They point out the positive correlation between self-regulation and hours of study and school grades (McClelland \& Cameron, 2011; Zimmerman, 2008) but also a negative correlation with substance use (Garcia del Castillo, Dias, \& Castelar-Perim, 2012; Gardner 
et al., 2006; Wills \& Dishion, 2004). These results suggest that students with higher self-regulation might achieve better in school and involve less in smoking or alcohol use. Moreover, they suggest also a consistently higher correlation of long-term self-regulation with these variables, what might reinforce the bidimentional model and the determinant role of the time perspective in adolescent development (Hall \& Fong, 2007; Miller \& Brickman, 2004; Zimbardo \& Boyd, 1999). These might be exciting results that open new lines of research to deepen our understanding of the role this process plays in resilience (Gardner et al., 2008) and positive youth development (Gestsdottir \& Lerner, 2008).

\section{Conclusion}

In conclusion, this study allowed us to contribute to improve our knowledge about self-regulation in a fundamental stage of human development. With the presented studies, we adapted an existing version of an instrument measure to evaluate self-regulation to Portuguese context, but also contributed to the testing of new items that we expect to contribute to a more comprehensive and reliable vision of this developmental process in adolescence. For this purpose, two convenience samples were used, from public schools in the north of Portugal. As we previous noticed, the sample has a higher percentage of girls, in accordance with official statistics of Ministry of Education for Secondary Education (Direção-Geral de Estatísticas da Educação e Ciência, 2013) - about $44.4 \%$ boys and $55.6 \%$ girls in regular Secondary Education - that might be considered in the generalization of the data. Also pragmatic reasons for school selection, given geographical proximity of the researcher, may limit the generalization of our inferences. So future studies should retest this structure with more representative samples of the Portuguese adolescent population. Also the collection of data about parents' socio-economic or educational level can be important for a more detailed analysis of this process.

In the end, the ASRI-2 consists of 43 items, with 19 for short-term and 24 for long-term self-regulation. Given the recent nature of the measure, future studies will test the stability of this structure, either in their validity or in reliability, particularly temporal reliability. Apart from the limitations, this study might have a substantial contribution to a better knowledge of self-regulation in adolescence, opening new lines for research and for the development of youth positive development programs.

\section{References}

Annesi, J. J., \& Gorjala, S. (2010). Relations of selfregulation and self-efficacy for exercise and eating and BMI change: A field investigation. BioPsychoSocial Medicine, 4:10. doi:10.1186/1751-0759-4-10
Bilde, J., Vansteenkiste, M., \& Lens, W. (2011). Understanding the association between future time perspective and self-regulated learning through the lens of self-determination theory. Learning and Instruction, 21(3), 332-344. doi:10.1016/j.learninstruc.2010.03.002

Borsa, J. C., Damásio, B. F., \& Bandeira, D. R. (2012). Cross-cultural adaptation and validation of psychological instruments: Some considerations. Paidéia (Ribeirão Preto), 22(53), 423-432. doi:10.1590/1982-43272253201314

Carretero-Dios, H., \& Pérez, C. (2007). Standards for the development and review of instrumental studies: Considerations about test selection in psychological research. International Journal of Clinical and Health Psychology, 7, 863-882.

Demetriou, A. (2000). Organization and development of self-understanding and self-regulation: Toward a general theory. In M. Boekaerst, P. R. Pintrich, \& M. Zeidner (Eds.), Handbook of self-regulation (pp. 209-251). San Diego, CA: Academic Press.

Dias, P. C., Garcia del Castillo, J. A., \& Schwarzer, R. (2008). Estudo de adaptação da Escala de Auto-Regulação (Schwarzer, Diehl, \& Schmitz, 1999) para a população portuguesa. In A. P. Noronha, C. Machado, L. Almeida, M. Gonçalves, S. Martins, \& V. Ramalho (Coords.), Actas da XIII Conferência Internacional de Avaliação Psicológica: Formas e contextos [edição em cd-rom] (s.p.). Braga, Portugal: Psiquilibrios Edições.

Diehl, M., Semegon, A. B., \& Schwarzer, R. (2006). Assessing attention control in goal pursuit: A component of dispositional self-regulation. Journal of Personality Assessment, 86(3), 306-317. doi:10.1207/s15327752jpa8603_06

Direção-Geral de Estatísticas da Educação e Ciência. (2013). Educação em números: Portugal 2013. Lisboa, Portugal: DGEEC.

Elliot, A. J., Thrash, T. M., \& Murayama, K. (2011). A longitudinal analysis of self-regulation and well-being: Avoidance personal goals, avoidance coping, stress generation, and subjective wellbeing. Journal of Personality, 79(3), 643-674. doi:10.1111/j.1467-6494.2011.00694.x

Garcia del Castillo, J. A., \& Dias, P. C. (2009). Autoregulação, resiliência e consumo de substâncias na adolescência: Contributos da adaptação do questionário reduzido de auto-regulação. Psicologia, Saúde $e$ Doenças, 10(2), 205-216.

Garcia del Castillo, J. A., Dias, P. C., \& Castelar-Perim, P. (2012). Autorregulação e consumo de substâncias na adolescência. Psicologia: Reflexão e Crítica, 25(2),238-247. doi:10.1590/S0102-79722012000200005

Garcia del Castillo, J. A., Dias, P. C., Diaz-Pérez, J., \& Garcia del Castillo-López, A. (2012). The mediating role of self-regulation in cigarette smoking and alcohol use among young people. Anales de Psicologia, 28(1), 1-10. 
Gardner, T. W., Dishion, T. J., \& Connell, A. M. (2008). Adolescent self-regulation as resilience: Resistance to antisocial behavior within the deviant peer context. Journal of Abnormal Child Psychology, 36(2), 273-284. doi:10.1007/s10802-007-9176-6

Gardner, T. W., Dishion, T. J., \& Posner, M. I. (2006). Attention and adolescent tobacco use: A potential self-regulator dynamic underlying nicotine addiction. Addictive Behaviors, 31(3), 531-536. doi:10.1016/j.addbeh.2005.05.018

Gestsdottir, S., Bowers, E., von Eye, A., Napolitano, C. M., \& Lerner, R. M. (2010). Intentional selfregulation in middle adolescence: The emerging role of loss-based selection in positive youth development. Journal of Youth and Adolescence, 39(7), 764-782. doi:10.1007/s10964-010-9537-2

Gestsdottir, S., \& Lerner, R. M. (2008). Positive development in adolescence: The development and role of intentional self-regulation. Human Development, 51(3), 202-224. doi: $10.1159 / 000135757$

Gibbons, F. X., Gerrard, M., Reimer, R. A., \& Pomery, E. A. (2006). Unintentional behavior: A subrational approach to health risk. In D. T. D. Ridder, \& J. B. F. de Wit (Eds.), Self-regulation in health behavior (pp. 45-70). Chichester, United Kingdom: John Wiley \& Sons.

Hagger, M. S., Wood, C. W., Stiff, C., \& Chatzisarantis, N. L., (2010). Self-regulation and self-control in exercise: The strength-energy model. International Review of Sport and Exercise Psychology, 3(1), 62-86. doi:10.1080/17509840903322815

Hall, P. A., \& Fong, G. T. (2007). Temporal selfregulation theory: A model for individual health behavior. Health Psychology Review, 1(1), 6-52. doi:10.1080/17437190701492437

Henson, R. K., \& Roberts, J. K. (2006). Use of exploratory factor analysis in published research: Common errors and some comment on improved practice. Educational and Psychological Measurement, 66(3), 393-416. doi:10.1177/0013164405282485

Hofer, J., Busch, H., \& Kärtner, J. (2011). Self-regulation and well-being: The influence of identity and motives. European Journal of Personality, 25(3), 211-224. doi:10.1002/per.789

Heywood, H. B. (1931). On finite sequences of real numbers. Proceedings of the Royal Society of London, 134(824), 486-501.

Husman, J., \& Lens, W. (1999). The role of the future in student motivation. Educational Psychologist, 34(2), 113-125. doi:10.1207/s15326985ep3402_4

Kleine, R. B. (2010). Principles and practice of structural equation modelling (3rd ed.). New York, NY: Guilford.

Lerner, R. M., Lerner, J. V., Bowers, E. P., Lewin-Bizan, S., Gestsdottir, S., \& Urban, J. B. (2011). Self-regulation processes and thriving in childhood and adolescence: A view of the issues. New Directions for Child and Adolescent Development, 133, 1-9. doi:10.1002/cd.300
Luszczynska, A., Diehl, M., Gutiérrez-Doña, B., Kuusinen, P., \& Schwarzer, R. (2004). Measuring one component of dispositional self-regulation: Attention control in goal pursuit. Personality and Individual Differences, 37(3), 555-566. doi:10.1016/j.paid.2003.09.026

MacDonald, A., \& Palfai, T. (2008). Predictors of exercise behavior among university student women: Utility of a goal-systems/self-regulation theory framework. Personality and Individual Differences, 44(4), 921-931. doi:10.1016/j.paid.2007.10.024.

Matsunaga, M. (2010). How to factor-analyse your data right: Do's, don'ts, and how-to's. International Journal of Psychological Research, 3(1), 97-110.

McCabe, L. A., \& Brooks-Gunn, J. (2007). With a little help from my friends?: Self-regulation in groups of young children. Infant Mental Health Journal, 28(6), 584-605. doi:10.1002/imhj.20155

McClelland, M. M., \& Cameron, C. E. (2011). Self-regulation and academic achievement in elementary school children. New Directions for Child and Adolescent Development, 133, 29-44. doi:10.1002/cd.302

Miller, R. B., \& Brickman, S. A. (2004). A model of future oriented motivation and self-regulation. Educational Psychology Review, 16(1), 9-33. doi:10.1023/B:EDPR.0000012343.96370.39

Moilanen, K. L. (2007). The Adolescent Self-Regulatory Inventory: The development and validation of a questionnaire of short-term and long-term self-regulation. Journal of Youth and Adolescence, 36(6), 835-848. doi:10.1007/s10964-006-9107-9

Moilanen, K. L., Goodvin, R., Crockett, L., \& Raffaelli, M. (2009). Approaches to the measurement of self-regulation from infancy through early adulthood. Unpublished manuscript, University of Nebraska, Lincoln, NE.

Muthén, L. K., \& Muthén, B. O. (2004). Mplus user's guide (3rd ed.). Los Angeles, CA: Muthén \& Muthén.

Pestana, M. H., \& Gageiro, J. M. (2005). Análise de dados para ciências sociais: A complementaridade do SPSS (4th ed.). Lisboa, Portugal: Edições Sílabo.

Pilati, R., \& Laros, J. A. (2007). Modelos de equações estruturais em Psicologia: Conceitos e aplicações. Psicologia: Teoria e Prática, 23(2), 205-216. doi:10.1590/S0102-37722007000200011

Raffaelli, M., Crockett, L. J., \& Shen, Y. L. (2005). Developmental stability and change in self-regulation from childhood to adolescence. Journal of Genetic Psychology, 166(1), 54-75. doi:10.3200/GNTP.166.1.54-76

Schwarzer, R. (1999). Self-Regulation. Retrieved from http://userpage.fu-berlin.de/ health/selfreg_g.htm

Silbereisen, R. K., \& Lerner, R. M. (2007). Approaches to positive youth development. London, United Kingdom: SAGE.

Wills T. A., \& Dishion, T. J. (2004). Temperament and adolescent substance use: A transactional analysis of emerging self-control. Journal of Clinical Child \& Adolescent Psychology, 33(1), 69-81. doi:10.1207/S15374424JCCP3301_7 
Zimbardo, P. G., \& Boyd, J. N. (1999). Putting time in perspective: A valid, reliable individual-differences metric. Journal of Personality and Social Psychology, 77(6), 1271-1288. doi:10.1037/0022-3514.77.6.1271

Zimmer-Gembeck, M. J., \& Skinner, E. A. (2008). Adolescents coping with stress: Development and diversity. Prevention Researcher, 15(4), 3-7.

Zimmer-Gembeck, M. J., \& Skinner, E. A. (2011). Review: The development of coping across childhood and adolescence:Anintegrativereview and critique ofresearch. International Journal of Behavioral Development, 35(1), 1-17. doi:10.1177/0165025410384923

Zimmerman, B. J. (2008). Investigating self-regulation and motivation: Historical background, methodological developments, and future prospects. American Educational Research Journal, 45(1), 166-183. doi:10.3102/0002831207312909

Paulo César Dias is an Auxiliar Professor of the Faculdade de Filosofia of the Universidade Católica Portuguesa.

José António Garcia del Castillo is the Director of the Instituto de Investigación de Drogodependencias (INID) and Full Professor of the Universidad Miguel Hernández.

Kristin L. Moilanen is an Assistant Professor in the College of Education and Human Services at West Virginia University.

Received: May 8, 2013

1st Revision: Apr. 24, 2014

2nd Revision: May 20, 2014

Approved: June 2, 2014

How to cite this article:

Dias, P. C., Gracia del Castillo, J. A., \& Moilanen, K. L. (2014). The Adolescent Self-Regulatory Inventory (ASRI) adaptation to Portuguese context. Paidéia (Ribeirão Preto), 24(58), 155-163. doi: 10.1590/1982-43272458201403 


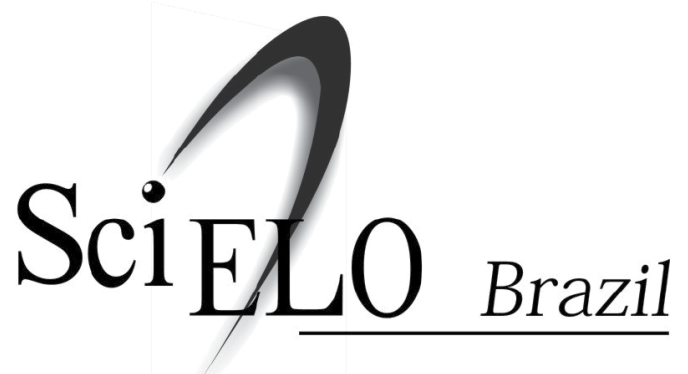
Paidéia (Ribeirão Preto) is a four-monthly publication available in full-text in the Scientific Electronic Library Online - SciELO.

The SciELO interface provides easy access to the tables of content and to the full-text articles.

The SciELO interface also provides the retrieval of articles by the author's name, the words from title, abstract and descriptors, in addition to providing bibliometric indicators and consultation indicators.

The articles are enriched with connections to the LILACS, MEDLINE and PubMed databases.

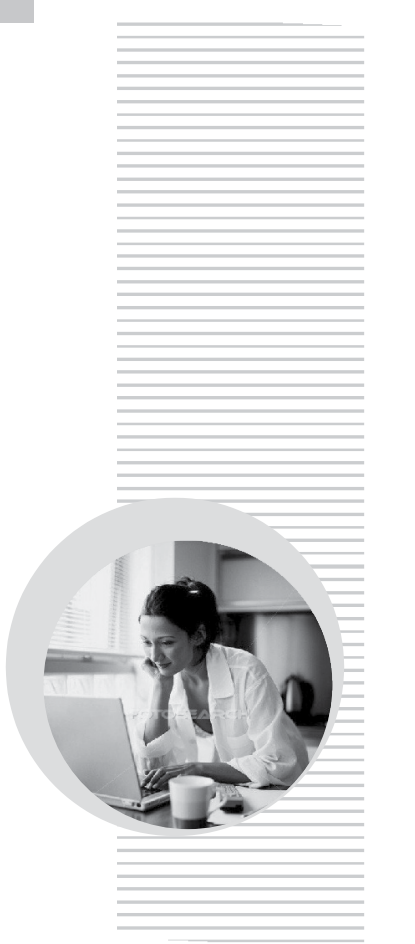

Paidéia (Ribeirão Preto) is a part of SciELO Brazil:

\section{www.scielo.br/paideia}

The SciELO interface provides access to a network of SciELO websites, gathering the major scientific journals of Latin America, Caribbean, Spain, Portugal and South Africa:

\section{www.scielo.org}

The electronic library is a project developed by the São Paulo Research Foundation (FAPESP), in partnership with the Latin American and Caribbean Center on Health Sciences Information (BIREME) and the National Council for Scientific and Technological Development (CNPq). 